Beginning life as a doctoral dissertation, Builders and Deserters convincingly, although occasionally in overly dense prose, illustrates the tremendous difficulties entailed in reeducating a generation according to a Marxist-socialist model. This informative book also adds to the historiography of Stalinism: indeed, by illustrating the rigidity of the paradigm of an allpowerful police state, the author joins the choir of social historians who have emphasized the dynamics of Soviet society under Stalin and, consequently, have criticized the reliability of the concept of totalitarianism as an explanatory model.

J.-Guy Lalande

St. Francis Xavier University

Veronica Strong-Boag and Carole Gerson. Paddling Her Own Canoe: The Times and Texts of $E$. Pauline Johnson, Tekahionwake. Toronto: University of Toronto Press, 2000. Pp. 331.

In the introduction to his 1889 anthology of Canadian poetry, Songs of the Great Dominion, W.D. Lighthall opined that a "peculiar feature" of Canadian literature was the strength of its "lady singers." One "poetess" who caught his attention was "E. Pauline Johnson, daughter of Head-Chief Johnson, of the Mohawks of Brantford." Her poetry, he said, was "of a high stamp and of great interest on account of her descent." Lighthall's interest in Johnson - whom he considered a friend - was part of his larger interest in Native history. In other words, it was her "descent," more than her poetry, that mattered. She fit the part of Indian Princess: romantic, exotic, Other. But Johnson was infinitely more complex. Through her voluminous writing and her many stage performances she presented a thoughtful, engaging, and stillrelevant critique of imperial Canada. It is this Pauline Johnson and not Lighthall's "lady singer" that is the subject of Paddling Her Own Canoe: The Times and Texts of E. Pauline Johnson, Tekahionwake, by Veronica Strong-Boag and Carole Gerson. Their Johnson "talked back" to the dominant culture and to an emerging national narrative rooted in notions of European and male superiority and privilege. "In the high age of Anglo-Saxon imperialism and patriarchy she was, we argue, a figure of 
resistance, simultaneously challenging both the racial divide between Native and European, and the conventions that constrained her sex. Her vision of Canada, of First Nations, and of women, articulated in print and on stage, was very different from that set forth by the Fathers of Confederation in 1867.”

Johnson was born in 1861 to a Mohawk father and an English mother. Called Chiefswood, her family home on Six Nations territory near Brantford, Ontario, welcomed and sustained its mixed-race heritage. In this "bicultural experiment” Mohawk culture and traditions existed beside a piano and a silver tea service. Even the architecture of Chiefswood spoke to the home's doubleness: one set of doors faced the Grand River, another set, the county concession road, "opposite entrances symbolically welcoming both Native and White." At the same time, Johnson's parents stressed middle-class respectability: formal education and religious observance were emphasized, appropriate behaviour and personal reserve cultivated. Instilled with a love of literature at a young age, Johnson started writing and performing as a teenager. As an adult she would turn it into a career. Although her mother took a dim view of her desire to pursue something so unrespectable and unladylike as a stage career, Johnson persisted. Because of her English heritage she was able to embrace the possibilities, opportunities, and independence of the New Woman in a way that Native women could not. An Anglo-American phenomenon from the 1880s to the 1920s, New Women sought careers as teachers, doctors, journalists, and writers and in the process pushed the boundaries of appropriate and inappropriate roles for women.

In time Johnson became the Dominion's best-known performer. Variously billed as "The Indian Poet-Reciter," "The Iroquois Indian Poet-Entertainer," and "The Mohawk AuthorEntertainer," she performed in venues across Canada and in London, England. Conscious of the related imperatives to entertain and not to alienate her audiences, Johnson walked a fine line: she took aim at gender conventions and Native-White relations but she did so carefully, relying on humour, sarcasm, and patriotism. "Yet however flawed, deferential, and incomplete her formulation, Johnson challenged a prevailing view of Canada, which, like that of the other dominions, granted superior privileges to European settlers." In poems like "A Cry from an Indian Wife" and "The Song My Paddle Sings," Johnson asserted Native rights and celebrated the physical strength of women. She imagined a nation along egalitarian lines, one that included a place for both First Nations and the second sex. 
But Johnson suffered for her art. Penury was never far behind. At the end of her life, dying of breast cancer in Vancouver, she lived in poverty. Testifying to her public persona, Vancouver closed its public offices and flew its flags at half-mast on the day of her funeral. The Duke of Connaught, the Governor General, saw that her ashes were placed in Stanley Park. "Today her modest monument in Stanley Park still looks westward, a reminder of that fairer future which the paddler from Six Nations wished for Canada.”

Drawing on post-colonial and feminist theory, Paddling Her Own Canoe is a theoretically sophisticated book and, mercifully, that theory does not intrude in what is also a very readable book. But as much as post-colonial and feminist theory leads to an original reading of the times and texts of Pauline Johnson, it also inhibits the authors. In the introduction Strong-Boag and Gerson address the question of what it means for two "Euro-Canadian feminist academics...to take up the story of a Mohawk-English Canadian woman." This is their answer: "Unlike First Nations people who, as Celia Haig-Brown has noted, 'are border workers by the nature of their aboriginal claims and their persisting marginalization by Canadian society' and 'some non-Native people who choose to remain in the border area,' we presume to be no more than occasional visitors. As visitors, we see our position as 'speaking nearby,' to borrow a phrase from Trinh T. Minh-ha."

Sensitive to the charge of appropriation and preferring to speak nearby, the authors lose a wonderful opportunity to explore Johnson herself. At the end of the book the reader leaves with a deeper understanding of imperial Canada and Johnson's intellectual project, but not with a deeper understanding of Johnson. To be sure, the problem is one of sources: Johnson's intimate records were destroyed. As a result, Strong-Boag and Gerson write, "we do not presume to know who Pauline Johnson was 'under the skin." "But the problem is also the authors' reticence. At one point they argue that "it takes a poet to catch a poet, to capture the larger complexity of a woman whose many published writings took different stances in different situations." They then add that "however much we two professors apply our academic training to illuminate Johnson's historical context and argue for her significance as a Canadian cultural figure, the most visceral connection belongs to First Nations women writers.” This implies a standpoint epistemology - that only Native women can know Native women - and it underestimates one's ability to make connections across time and space and difference of all kinds. 
Having situated themselves as occasional visitors who will only speak nearby, Strong-Boag and Gerson do not permit themselves to connect on a visceral level with Johnson, to explore that connection and share it. Yes, they are Euro-Canadian academics, but they are also human beings endowed with an imagination and with the ability to empathize with someone from a different era and from a different background. Mixed metaphors notwithstanding, they have - indeed, we all have - the ability to walk a mile in someone else's shoes and, in the process, to get to know that person under the skin.

Donald Wright

Brock University

\section{Alison Taylor. The Politics of Educational Reform in Alberta. Toronto: University of Toronto Press, 2001. Pp. 400.}

I read this fine book against the backdrop of the latest crisis around education restructuring in Ontario. The Conservative government seized control of three of the province's largest school boards to enforce spending cuts in line with the centralized funding formula. These boards were the most recent site of resistance in the ongoing struggle around education reform in Ontario since 1995, when the Conservatives were first elected. Alison Taylor's book provides important tools to help understand these struggles. This book offers powerful generalizations about contemporary education reform strategies that are grounded in the rich and detailed examination of a case study: the implementation of education reform in the early years of the Klein government in Alberta, 1993-95. The Klein government played an important pioneering role in the development of the right-wing education reform agenda in Canada.

Perhaps this book's greatest single contribution is that it shows the logic of the right-wing education reform agenda. It is tempting, when governments do things that do not make sense from one's own perspective, to suggest that they are simply making mistakes that will be set right after the next election. This book does not give in to that temptation. Rather, it reveals the rationality of the Klein education reform agenda, showing it as a deliberate strategy 